\title{
State aid, EU maritime transport policies and competitiveness of EU country fleets
}

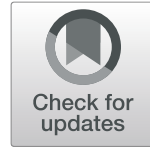

Javier Bilbao-Ubillos ${ }^{1 *} \mathbb{D}$, Ana Fernández-Sainz ${ }^{2}$ and Rosa Payán-Azkue ${ }^{1}$

\begin{abstract}
Aim and purposes: This study conducts an across-the-board comparative analysis of the impact of the main measures used by the 10 leading maritime nations of the EU on the relative competitiveness of the fleets that they control, covering the period from 1996 to 2011. We propose two models to compare the relative effectiveness of the maritime policy measures implemented: one for the full set of countries and measures and the other specifically for each maritime nation.

Findings: The estimation results make us conclude that generally the measures adopted in national-level maritime policies (tonnage tax, second register and other measures) seem to have been effective in that they have had a positive effect on the competitiveness of controlled fleets, but with uneven impact on the fleets of each country.
\end{abstract}

Keywords: Relative effectiveness of the maritime policy measures, European Union, Competitiveness of controlled fleets, Protectionism and state aid

\section{Introduction}

In the European Union (EU), maritime transport, despite taking a relatively small proportion of gross domestic product (1\%), represents more than 640,000 direct jobs and $40 \%$ of global gross tonnage ([4], p. 6). At European level, nearly $75 \%$ of the Union's external trade and $37 \%$ of the internal is conducted by sea [24].

Like other areas of production, the maritime industry has had to endure competition from emerging countries in the past few decades, including competition from a number of jurisdictions with more relaxed standards of fleet operating requirements (the so-called "flags of convenience" -FOCs ${ }^{1}$ - or "open registries"). The relative fleet capacity of such countries has increased in detriment to

\footnotetext{
${ }^{1}$ According to Gregory [19], flags of convenience are a tool developed by the modern maritime business to circumvent Western labor and tax regulations through international vessel registration, posing a significant risk to the well-being of global seafarer labor and contribute to the decline in prominence of traditional fleets.
}

\footnotetext{
* Correspondence: javi.bilbao@ehu.es

'Department of Applied Economics I, University of the Basque Country (UPV/

EHU), Avda. Lehendakari Agirre, 83, 48105 Bilbao, Spain

Full list of author information is available at the end of the article
}

traditional seafaring countries, including numerous EU Member States. In 1970 the world's fleet was distributed as follows in terms of cargo capacity (Dead Weight Tonnage or DWT): $65 \%$ was owned by developed countries, $6 \%$ by developing countries and $22 \%$ by open registry countries. In 2015 the figures were 16\%, 27\% and 56\% respectively (UNCTAD [41], p.42).

It must be taken into account on the one hand that FOC countries (Panama, Liberia, the Marshall Islands, Malta, the Bahamas, Cyprus, Saint Vincent and the Grenadines and Antigua and Barbuda) offer certain advantages: i) easier registration; ii) the ability to use cheaper foreign labour; and iii) lower safety requirements. Moreover, foreign owners do not usually pay income tax in these countries.

On the other hand, fleet development in new, emerging maritime nations (Hong Kong, Singapore, China, Korea, Indonesia, India, Taiwan and Saudi Arabia) has been associated mainly with four factors: i) development of a trade policy oriented towards foreign trade which generates the availability of cargo required to set up

(c) The Author(s). 2021 Open Access This article is licensed under a Creative Commons Attribution 4.0 International License, which permits use, sharing, adaptation, distribution and reproduction in any medium or format, as long as you give appropriate credit to the original author(s) and the source, provide a link to the Creative Commons licence, and indicate if changes were made. The images or other third party material in this article are included in the article's Creative Commons licence, unless indicated otherwise in a credit line to the material. If material is not included in the article's Creative Commons licence and your intended use is not permitted by statutory regulation or exceeds the permitted use, you will need to obtain permission directly from the copyright holder. To view a copy of this licence, visit http://creativecommons.org/licenses/by/4.0/. 
their own fleets; ii) investment in infrastructures that make effective, competitive maritime transport possible; iii) accumulation of the capital needed to invest in ships; and iv) in some cases the availability of cheaper labour.

The development of large fleets in these recently industrialised countries (closely linked to the type of trade in which they engage) has changed the traditional make up of the global fleet, in terms not just of ownership but also of specialisation in certain types of vessel.

The importance of these changes lies in the fact that the competitive pressures exerted by both types of country in certain fleet segments has reduced or entirely eliminated the market presence of European operators. ${ }^{2}$ As a result, development of the European fleet in the past 30 years has taken place under a framework of protectionist policies. In almost all EU countries a number of state support instruments have been used to develop, or at least protect, national fleets based on arguments such as promoting the training and employment of seafarers or providing support for a maritime cluster.

Moreover, the exceptional nature of Community links to the beneficiaries of state aid introduces the concept of "controlled fleet" that includes both the fleet sailing under the flag of the country of reference (national flag) and vessels sailing under other flags which are owned by national companies (foreign flag). Thus, there are therefore two possibilities to define the relevant variable: the capacity of the controlled fleet or that of the national flagged fleet. In this paper we propose to use as variable of interest the controlled fleet (sailing under national or foreign flags).

This study conducts an across-the-board comparative analysis of the impact of the main measures used by the leading maritime nations of the $\mathrm{EU}$ on the relative competitiveness of the fleets that they control, covering the period from 1996 to 2011. The paper is organised as follows: Section 2 reviews the changes over time in Community policy on maritime transport; Section 3 identifies the main measures implemented by Member States under that policy; Section 4 selects a variable and a competitiveness indicator with which to estimate the impact of the measures taken; Section 5 draws up the models and outlines the results of the estimation; and the final section presents conclusions.

\section{Changes over time in maritime transport policies in the EU}

Policies in support of maritime transport have traditionally been justified with the argument that "trade follows

\footnotetext{
${ }^{2}$ According to the UNCTAD [40], China's development of an oiltanker fleet from 2006 to 2011 to carry a larger percentage of the country's oil imports under its own flag resulted in a $16 \%$ drop in the market share of European shipowners on the route between the Middle-East and China.
}

the flag" [3]. In the case of the EU the specific factors favouring protectionism in the sector are the following:

- the recession in the global economy following the first oil crisis in 1973, which reduced demand for transport and thus created significant overcapacity in the world's maritime transport market;

- potential competition from new maritime nations which used protectionist policies to develop their own fleets;

- FOCs which offered a more competitive environment than European registries.

The loss of competitiveness among fleets from traditional maritime nations resulted in a major reduction in capacity in European fleets due to re-flagging under international registries (flags of convenience) and a net loss of tonnage (scrapping, sale, etc). This spurred European governments into setting up unilateral support measures such as direct and indirect subsidies and discriminatory practices, resulting in a wide range of different measures which distorted competition between the national registries of EU Member States.

However, it can be argued that Community developments on matters of maritime transport policy came too late. As ([31], p. 187) argue, "For many years, the European Community (EC) (later the European Union) did not have a shipping policy". Until 1985 there were no commitments on this matter, and those that came later were conditioned mainly by the decline in Community fleets and the pressure exerted by newly joined Member States with significant maritime interests (e.g. Greece in 1981). These two factors resulted in the issuing of the Communication Progress towards a Common Transport Policy. Maritime Transport [17], the main goal of which was to tackle the problems of competitiveness in the sector and apply the basic principles of the Treaty Establishing the European Economic Community to maritime transport (Regulations 4055/86, 4057/86, 4058/86).

In the words of Roe [35], p.3: "Regulation 4056/86 was inconsistent, incoherent, and irrational in the context of the Treaty of Rome, the principles of the EU and their relatively rigid application to all other sectors. For 20 years, simply its existence was a clear policy failure as it violated the most significant principle that drives the EU in all that it does-that of free competition to achieve maximum economic benefits across the EU". In 1989 a framework was set up to bring together the measures applied by Member States [16]. These measures were revised and redefined in 1997 [14] and maintained in 2004 [13]. They were only finally eliminated in 2008 despite almost universal condemnation apart from a few shipowners that were the major beneficiaries from the protection offered. 
Thus Paixao and Marlow [32], p. 364 think that the market players appear to focus constantly on numerous issues already addressed in several EU communications on transport and short sea shipping which have proven not to provide a solution. Some protectionist practices in this sector have gradually been eliminated within the EU, but the resulting policy can still not be described as fully liberal. State aid is still provided for maritime transport, and Regulations such as $\mathrm{n}^{\circ} 3577 / 92$ (free provision of maritime cabotage services) do not open up cabotage traffic to all nationalities but limit it to vessels registered in the EU. ${ }^{3}$

As stated by Bredima and Tzoannos [6], one important aspect of the development of Community maritime policy is that it was founded on the basis of the different interests of governments and powerful groups in Member States, and was thus focused on their own national industries. As a result the legislation produced did not take a harmonic approach to some aspects, such as trading conditions, technical requirements for vessels, crew requirements or the taxation of shipping companies. Member States took unilateral measures which in some cases distorted competition in the internal market.

A similar situation can be seen today: although there is a framework of development for state aid to the maritime transport sector which sets upper limits on the aid available to EU Member States, the various national legislations have the power to set the size of those limits and regulate their application to different types of traffic. Moreover, divergences can be seen in other aspects such as crew requirements (minimum crew rosters and nationality of seafarers). These two aspects seem to distort competitiveness between European registries and cause fleet transfers from one Member State to another (especially in cabotage).

The widespread use of FOCs as a way of increasing the competitiveness of the fleets of developed countries (though it is currently also spreading to developing

\footnotetext{
${ }^{3}$ In its Fifth report on the implementation of Council Regulation (EEC) No 3577/92 applying the principle of freedom to provide services to maritime cabotage (2001-2010) European Commission [11] believes that the Regulation is fit for its purpose and does not require revision. But this report states: "It appears that abolishing barriers in access to cabotage markets has not led to any significant increase in the number of shipowners interested in providing cabotage services. This might be linked to the inherent features of the cabotage market, which, with a few exceptions of routes of very high commercial interest, consists in rather small passenger traffics and limited cargo volumes.

Furthermore, the geographical position often does not give any advantage to maritime services compared to land transport, for instance by requiring specific technical features of the ships (e.g. ships sailing in the northern Europe often need to have an ice class).Moreover, it should be noted that some shipowning companies ensure their presence on cabotage markets of other Member States by acquiring the shares in national shipowning companies rather than by physically deploying the cabotage services ([11], p. 10)"
}

countries such as China) has become a problem for European governments due to the consequences of the "flagging out" of the fleet for tax revenue, employment, the setting up of clusters and maritime expertise itself.

Faced with this loss of competitiveness of national fleets and flagging out to more competitive flags, governments began (freely at the beginning and subsequently under EU guidelines for state aid to maritime transport) to set up a number of aids aimed at forestalling flagging out, holding on to fleets and even attracting vessels currently sailing under foreign flags (mainly FOCs).

The 2009/2018 European maritime transport strategy, presented by the EC in January 2009, aimed to make this sector "more competitive and sustainable" and was based on several foundations: sustainable development, economic growth, the opening of markets in a context of fair competition and high social and environmental standards ([4], p. 6). In fact, Valletta declaration on the EU's maritime policy outlines priorities for the EU's maritime transport policy, focusing on competitiveness, digitalisation and decarbonisation $[8,9]$.

According to Sdoukopoulos et al. [36] the main strategic goals for the European maritime transport system may be summarized to the following: 1 . Develop and maintain an attractive framework for quality shipping and quality of operations in Europe; 2. Invest in human capital; 3. Promote greener maritime transport; 4 . Give priority to the enforcement of existing Community and International rules that will lead to a safe and secure system; 5 . Support EU energy security; 6 . Promote short sea connections between all maritime regions of the European continent, addressing the road congestion problems while reducing significantly the environmental impact of the overall transport chain; 7. Improve Europe's commercial sea ports; 8 . Strengthen the competitiveness of the European maritime industries and their capacity to meet the environmental, energy, safety and human challenges by supporting research and innovation development.

Pallis [33] chronicles meticulously the stages by which the European Community (later the EU) has moved into the maritime transport policy field.

\section{Measures for promoting maritime transport adopted in EU member states}

Lloyd and AMRIE [25], p. 23 state that the justification for state aid (and therefore the goals of its impact) is to establish compensatory aid to promote the development of European maritime industries in the context of distorted international competition caused the competitive advantage offered by flags of convenience (FOCs). About $71 \%$ deadweight tonnage of the world's ships sails under

${ }^{4}$ Zamora [43] defines flagging out as "the practice of exporting vessels to other flags, but without losing financial control of their operations". 
foreign flags ([7], p. 22). In other words the idea is to tackle the trend towards flagging out the European fleet and resorting to FOCs.

Indeed, according to data from the Spanish Shipowners' Association (ANAVE) (drawn from several years) between 1975 and 2012 the global fleet grew by $190 \%$. Over the same period the five main open registries (Panama, Liberia, the Bahamas, Malta and Cyprus) recorded spectacular growth of $436 \%$. As a result, by $201245 \%$ of the global fleet was registered under flags of this type. However, the biggest growth in open registries took place between 1975 and 2000, with annual increases averaging $24 \%$ as compared to $10 \%$ increases in the size of the global fleet. The biggest exodus of vessels took place between 1990 and 2000. This trend is illustrated in Fig. 1.

However, to assess the effectiveness of the public sector policies implemented in the sector it is necessary to analyse the factors that influence flagging-out. According to an empirical study by Bergantino and Marlow [5], the most widely accepted reason for flagging out is a need to reduce operating costs. These authors state that until recently the need for a favourable fiscal environment was considered in the relevant literature to be a substantial factor in flag changes, but other factors may now be more significant. In any event, the consequences of flagging out can be assessed and the political response to the resulting problem can be reviewed.

Yannopoulos [42], p.197 states that "The existence of flags of convenience creates a distinct type of dualism in the international maritime transport industry. The market is split into two distinct segments (or sectors) operating under different labour costs and different conditions for efficiency. The first sector, to be called the established flag sector, comprises tonnage under registries of the traditional maritime nations. The second sector of this dual market, to be referred to as the flag of convenience sector, consists of vessels operating under open registry systems".

As stated by Chen et al. [7], there has been significant academic discussion of the reasons for, consequences of and legal governance of flagging out. The open registers or "flags of convenience" have primarily attempted to attract owners through four kinds of incentives: lower labour costs, reduced taxes, decreased safety and environmental regulation, and freedom from intervention by state government [34]. Because of these advantages, some scholars believe that the escalating adoption of FOC or open registration will be a long-term trend. However,"the practice of flagging out has also been criticized by scholars, since they believe that the consequences of FOCs include a negative impact on ship

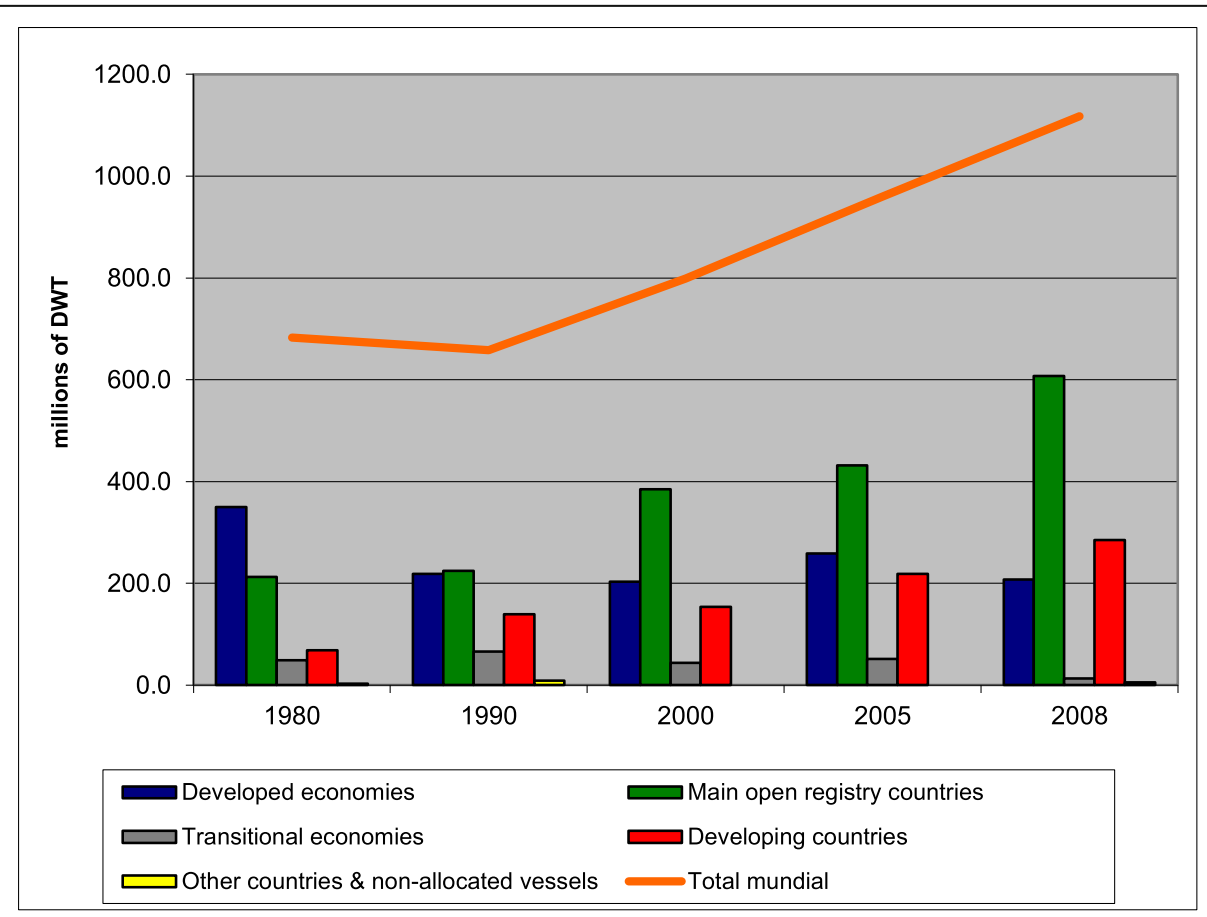

Source: Own elaboration based on data from UNCTAD (several years)

Fig. 1 Trend in fleet capacity (in DWT) by groups of countries and the global total, 1980-2008. Source: Own elaboration based on data from UNCTAD (several years) 
safety, the marine environment, and fair market competition" ([7], p. 23). In that sense Metaxas [28] was already anticipating that the costs of FOC institution far outweigh its benefits.

Luo, Fan and Li [26] consider that the high proportion of foreign-flagged vessels in the global fleet has implications not only for national and international public sector maritime policies but also for business strategies in the maritime industry. Traditional maritime nations are concerned at the reductions in their national fleets, the loss of tax revenue, the fall in employment in the maritime industry and adverse effects on national security.

\subsection{Classification of maritime transport policies}

Chief among the wide range of measures adopted by almost all Member States to improve the competitiveness of their fleets are fiscal and labour-related measures. The document Towards a New Maritime Strategy acknowledged the competitive advantage enjoyed by FOCs: for Community shipowners registering their vessels in an open registry may be an important factor in ensuring that they are internationally competitive, as it entails savings in labour costs and taxation that may be close to $\$ 1$ million per year [15].

The measures implemented in an effort to relax the burden on firms are essentially the following: reduction of operating costs, introduction of second registers (as a particular way to reduce those costs), changes in taxation systems via the more favourable "tonnage tax" and other measures such as aids for investment and subsidies.

\subsection{Reduction of operating costs compared to labour costs}

One of the main arguments used in the maritime community to explain the lack of competitiveness of the European fleet and the consequent flagging out of its vessels is the high wage cost of employing domestic crews. Manning costs for a standard vessel in 2012 accounted for $18.5 \%$ of total costs [2]. Thanopoulou [37] , p.368 states that although manning costs as a share of total costs are invariably between $9 \%$ and $15 \%$, the options available to governments to support the potential competitiveness of their national fleets have been very limited. The focus has invariably been on manning costs, due to the tradition of governments regulating crew sizes and wages.

Guidelines on state aid have taken reducing labour costs as one of their main measures for putting the operating cost of EU national flags on a par with those of FOCs. This should serve to increase the international competitiveness of European fleets by transferring cost savings to charters.
Within this section, four types of aid related to manning costs are specified:

a) Tax regime for seafarers

The Commission permits a favourable tax regime for seafarers, which should be based on tax exemptions depending on time spent on board vessels outside Community territorial waters or on tax deductions per day spent on such vessels [13]. With a view to protecting Community jobs, in 2004 these exemptions were limited to "Community seafarers", defined as follows:

- Community/EEA citizens, in the case of seafarers working on board vessels (including Ro-Ro ferries) providing scheduled passenger services between ports of the Community;

- all seafarers liable to taxation and/or social security contributions in Member State, in all other cases.

\section{b) Social security contributions}

The Commission supports the idea of minimising social security contributions for Community seafarers [13]. In 2004 reductions in social welfare burdens were also limited to "Community seafarers" sailing on board vessels registered in Member States.

iii) Repatriation costs (crew relief)

Aid is also envisaged in paying the cost of repatriating Community seafarers on board vessels registered in the Community, particularly from the high seas. In 1989 this aid was limited to $50 \%$ of the cost incurred, but the revised wording from 1997 and 2004 sets no individual upper limit to such aid but rather considers a joint limit for all benefits received: such benefits must not exceed the total amount in taxes and social security contributions paid for maritime transport activities and seafarers [13].

\section{iv) Training costs}

The Commission considers training to be essential, asserting that there is a need for seafarers to adapt to technological changes. One solution put forward by the Commission itself in 1989 was to transfer the relevant costs to state education and vocational training systems [16]. Subsequent wordings admit that training plans may include state aid provided that they are specific onboard training programmes and that it is the state itself which funds them [13]. 


\subsection{The creation of "second registers"}

In the 1980s, faced with flagged tonnage slipping away towards FOCs, numerous EU countries set up "second registers" (international registers) in an attempt to compete on an equal footing with actual FOCs. These second registers flagged vessels under certain islands or colonial territories such as the Canaries (Spain), Kerguelen (France), Gibraltar (UK), Aruba (the Netherlands), the Faroe Isles (Denmark) and Madeira (Portugal). Table 1 shows the main second registers alongside the main flags of convenience.

Adjusting the conditions of traditional registries to match those of FOC registries entailed making changes in both tax legislation (reducing or eliminating tax on the profits of shipping companies, allowing accelerated depreciation of vessels, reducing income tax rates and social security contributions) and labour legislation (admitting the employment of crews of any nationality). For this reason, the states involved decided that the best option was to set up "second registers". Most of these registers have some or all the characteristics of an FOC as defined in the 1970 Rochdale Inquiry on the shipping sector drawn up by the [20], p.19).

Within the group of "second registers", a distinction is drawn between "offshore registries" and "special registries":

- Offshore registries are located in overseas territories or possessions, and include registries in the Channel Islands, the Falkland Islands, the Isle of Man, the Turks and Caicos Islands and Gibraltar set up by the UK; in the Dutch Antilles set up by the Netherlands; and in the Kerguelen Isles and the Wallis and Futuna Isles set up by France.

- Special registries are located within the territory of the state. They include, in order of establishment, the Norwegian International Ship Register (NIS, 1987), the Danish International Register (DIS, 1988), the Portugal-Madeira register (1988) and the

Table 1 Countries that offered FOC and second register services in 2010

\begin{tabular}{|c|c|c|c|}
\hline \multirow{2}{*}{$\frac{\text { FOC }}{\text { Countries }}$} & & \multicolumn{2}{|c|}{ Second Registers } \\
\hline & & Countries & Registers \\
\hline Antigua and Barbuda & Bahamas & Brasil & Registro Especial Brasileiro (REB) \\
\hline Barbados & Belize & China & Hong Kong \\
\hline Bermudas (UK)) & Bolivia & & Macao \\
\hline Myanmar & Cambodia & Denmark & DIS \\
\hline Islas Caimán & Comoros & & Feroe Islands \\
\hline Cyprus & Equatorial Guinea & & Feroe Islands (FAS) \\
\hline $\begin{array}{l}\text { Second Register of France } \\
\text { (FIS) }\end{array}$ & $\begin{array}{l}\text { International Maritime Register of Germany } \\
(G I S)\end{array}$ & France & $\begin{array}{l}\text { Kerguelen Islands (French Southern and Antarctic } \\
\text { Lands) }\end{array}$ \\
\hline Georgia & Gibraltar (UK) & & Wallis and Futuna Islands \\
\hline Honduras & Jamaica & Germany & GIS \\
\hline Lebanon & Liberia & Italy & Second Register \\
\hline Malta & Marshall Islands & Netherlands & Netherlands Antilles \\
\hline Mauritius & Mongolia & New Zeland & Cook Islands \\
\hline Netherlands Antilles & North Korea & Norway & NIS \\
\hline Panama & Sao Tomé and Príncipe & Portugal & Madeira (MAR) \\
\hline $\begin{array}{l}\text { Saint Vicent and the } \\
\text { Granadines }\end{array}$ & Sri Lanka & Spain & Canary Islands (REC) \\
\hline \multirow[t]{9}{*}{ Tonga } & \multirow[t]{9}{*}{ Vanuatu } & Turkey & Second Register \\
\hline & & \multirow{8}{*}{$\begin{array}{l}\text { United } \\
\text { Kingdom }\end{array}$} & Anguilla \\
\hline & & & Bermudas \\
\hline & & & British Virgin Islands \\
\hline & & & Caymán Islands \\
\hline & & & Channel Islands \\
\hline & & & Falkland Islands \\
\hline & & & Gibraltar \\
\hline & & & Isle of Man \\
\hline
\end{tabular}


German International Register (GIS, 1988). According to the [20], p.20), this period of intensive creation of new registries was followed by a period of calm in which only one more or set up: the Canary Islands special registry in Spain (REC, 1992). However, a new upsurge in activity was observed from 1997 onwards, with the setting up of the Turkish second register (1997), the Brazilian special registry (1997) and the Italian second register (1998).

Unlike traditional registries, second registers may be open (i.e. may admit the registration of vessels by companies owned by non-nationals of the state in question) or closed (i.e. restricted to companies owned by state nationals). There are second registers for which only vessels operating in the international market are eligible (Germany's ISR and France's FIS), but Italy's registro internazionale, which initially only admitted vessels engaged in international trade, subsequently broadened its criteria to include those engaged in cabotage. The Spanish REC and the Danish DIS did likewise.

Admitting vessels engaged in cabotage means that fleets not subject to international competition can enjoy the incentives provided by second registers. It must also be taken into account that the free provision of cabotage services under Regulation 3577/92 does not open up this type of trade to all nationalities; rather, it is limited to Community vessels and therefore subject to differences in competitiveness between EU country flags.

Some authors consider that the setting up of these registries provided an effective alternative way of reducing the flagging-out of national fleets: for example the DIS has shown itself to be an effective alternative for avoiding the downward trend in the Danish fleet ([22], p.182). ${ }^{5}$ However, the unilateral adoption of these measures by certain states has led to a distortion in competition: for instance in the case of Belgium (which has no offshore registry) crews must be $100 \%$ Belgian nationals, while under the DIS only the ship's master is required to be a national.

\subsection{Tonnage tax}

The Community Guidelines on State Aid to Maritime Transport (97/C 205/05) acknowledged that the differences in competitiveness between vessels registered in

\footnotetext{
${ }^{5}$ It is true that the Danish maritime policy has been altered since then: On 10 April 2007, the Danish Parliament adopted the tonnage tax (N563/2001) and in 2006 the Danish Ministry of Economic Affairs published an Action Plan incorporating a range of initiatives including training, recruitment, standards and technical regulations, or specific tax schemes. Nowadays, the Danish fleet is growing in leaps and bounds: by April 2018, 703 ships fly the Danish flag (480 ten years before) (Danske [10]). The annual figures for the number of seafarers on board ships registered in the DIS for the year 2019 shows that 9847 persons were covered.
}

the Community and outside it (especially under FOCs) were attributable to tax costs - corporation tax and seafarers' social welfare payments - given that capital costs and the technologies available were practically the same all over the world.

As a result the main system of aid to encourage registration under national flags in most EU countries has been the introduction of a tonnage tax to replace generic corporation tax. Tonnage tax means basing tax payments on the registered tonnage of vessels multiplied by a fixed amount. According to Adriaansens [1] , p.9, there are three different models of tonnage tax in Europe:

- the Dutch model, introduced in 1996 and implemented by Belgium, Denmark, France, Germany, Ireland, Italy, the Netherlands, Poland, Sweden and the UK;

- the Norwegian model, dating from 1996, adopted by Finland; and

- the Greek model, introduced in 1957 and implemented by Cyprus and Malta.

This system is based on "flag neutrality", ${ }^{6}$ i.e. it is applicable to foreign-owned vessels controlled by domestic shipowners. These schemes do not therefore directly promote European flagging: they are intended rather to enhance the competitiveness of Community fleets in the market and promote European control of fleets.

\subsection{Other measures}

Some states have opted for different ways of promoting their fleets which can be classed generically as aids for investment and operating costs. The main forms of such aid are the following:

a) aid for investment to improve equipment on board vessels registered under national flags, and for the use of reliable, non-polluting vessels;

b) regional aids for investment awarded to Maritime companies in less favoured regions;

c) aid for funding public service obligations: aid to offset operating losses is incompatible with the common market, but subsidies for public service obligations can be authorised;

d) aid for restructuring (including privatisation): this aid is not specific to this sector but rather is permitted under Community guidelines on state aid for rescuing and restructuring firms in difficulty [12]; and

\footnotetext{
${ }^{6}$ Except in Italy, where vessels seeking to benefit from this tax system must fly the national flag.
} 
e) expressly authorised state aid for short-sea shipping under the second revision of state aid for the sector [13].

As well as these aids, shipping firms are authorised under "Fiscal treatment of ship owning companies" to adopt special measures for the accelerated depreciation of investments or tax exemption on profits obtained on the sale of vessels in case of reinvestment.

\subsection{Timing of the measures adopted}

Table 2 shows the main measures adopted by EU countries.

\section{Effectiveness of maritime transport policies adopted in the EU: relative competitiveness indicator}

State aid in the framework of Community maritime transport policy is mainly concerned with the need for a competitive European merchant fleet. It has been demonstrated that the decline of the fleet sailing under EU Member State flags as a result of its lack of competitiveness on a global scale was one of the main factors underlying the development of Community maritime policy.

When it comes to using changes in competitiveness as a yardstick for assessing the effectiveness of maritime transport policies, two methodological issues must be resolved: selecting the variable observed and the reference indicator.

\subsection{Selection of the variable observed: controlled fleet versus national flag}

The exceptional nature of Community links to the beneficiaries of state aid introduces a new concept: the "controlled fleet". Unlike flagging, control of a fleet means that its commercial and operational management is centred in a particular country but the fleet itself may sail under an open registry or a flag of convenience. According to the UNCTAD ([39], p.43), the "country of ownership indicates where the true controlling interest (i.e. parent company) of the fleet is located".

Thus, the controlled fleet includes both the fleet sailing under the flag of the country of reference ("national flag") and vessels sailing under other flags which are owned by national companies ("foreign flag"). Theoretically, there are therefore two possibilities when it comes to defining the relevant variable for observation: the capacity of the controlled fleet or that of the national flagged fleet.

The national flag is associated with one of the initial objectives of Community maritime policy (encouraging ships to register or re-register under the flags of Member States), but the notion of the "controlled fleet" fits better with the actual measures adopted by Member States in the light of the revision of the framework of state aid, aimed at holding onto maritime business and the consequent economic independence. Given the current makeup of the sector, we thus believe that the effectiveness of aid should be measured on the basis of the trend in the controlled fleet (sailing under national and foreign flags).

\subsection{Reference indicator: the concept of competitiveness in the field of maritime transport}

Thanopoulou [37] asserts that it is not initially possible to identify "competitiveness" with "profitability", given the highly cyclical nature of maritime transport. We have therefore opted for the most widely used exposed competitiveness indicator, i.e. potential market share, observing the trend in the relative shares of the cargo capacity of the controlled fleet (in DWT) for each country in a global context. In other words, an increase in the competitiveness of the fleet controlled by a particular country should entail an increase in its share of the total world market.

\subsection{Trend in the European fleet in terms of control and the flagged fleet}

According to data from Eurostat [18], p.94 the controlled fleet (sailing under national and foreign flags) of the EU-15 countries grew by $114 \%$ between 1995 and 2011, and that of the EU-27 by $106 \%$. Growth in the total global fleet over that period was $99 \%$. However, the growth recorded was not regular: between 1995 and 2008 growth in the fleets of the EU-15 (22\%) and EU-27 (21\%) exceeded the global average of $17 \%$, but in 2010 and 2011 there was a substantial slowdown in the growth of the European fleet measured both in terms of the EU-15 (9\%) and the EU-27 (8\%), with both falling below the global average of $12 \%$.

Table 2 Timing of the adoption of maritime transport policies by EU Member States

\begin{tabular}{|c|c|c|c|c|c|c|c|c|c|c|}
\hline Measure \Country & Germany & Belgium & Denmark & Spain & France & Greece & Italy & Netherlands & U.K. & Sweeden \\
\hline Tonage tax & 1999 & 2003 & 2002 & 2003 & 2004 & 2002 & 2005 & 1996 & 2000 & \\
\hline Second register & & & & & 2006 & & 1998 & & & \\
\hline Other measures & 2004 & 2003 & 2006 & 1997 & & 2007 & & 1996/2008 & & 2002 \\
\hline
\end{tabular}


Table 3 Trend in the share of the main EU maritime countries in the world fleet (national flag and controlled fleet in DWT), 19962011 (in \%)

\begin{tabular}{|c|c|c|c|c|c|c|c|c|c|c|c|c|c|c|c|c|c|c|c|c|}
\hline & \multicolumn{2}{|c|}{ Germany } & \multicolumn{2}{|c|}{ Belgium } & \multicolumn{2}{|c|}{ Denmark } & \multicolumn{2}{|c|}{ Spain } & \multicolumn{2}{|c|}{ France } & \multicolumn{2}{|c|}{ Greece } & \multicolumn{2}{|c|}{ Italy } & \multicolumn{2}{|c|}{ Netherlands } & \multicolumn{2}{|l|}{ U.K. } & \multicolumn{2}{|c|}{ Sweeden } \\
\hline & NF & $\mathrm{CF}$ & $\mathrm{NF}$ & $\mathrm{CF}$ & $\mathrm{NF}$ & $\mathrm{CF}$ & $\mathrm{NF}$ & $\mathrm{CF}$ & $\mathrm{NF}$ & $\mathrm{CF}$ & $\mathrm{NF}$ & $\mathrm{CF}$ & $\mathrm{NF}$ & $\mathrm{CF}$ & $\mathrm{NF}$ & $\mathrm{CF}$ & NF & $\mathrm{CF}$ & $\mathrm{NF}$ & $\mathrm{CF}$ \\
\hline 1996 & 0,9 & 2,7 & 0,0 & 0,6 & 1,1 & 1,8 & 0,1 & 0,5 & 0,6 & 1,1 & 6,8 & 17,4 & 1,1 & 1,8 & 0,5 & 0,9 & 0,8 & 3,1 & 0,3 & 2,1 \\
\hline 1997 & 1,1 & 3,1 & 0,0 & 0,6 & 1,0 & 1,7 & 0,1 & 0,5 & 0,6 & 1,1 & 6,1 & 17,6 & 1,0 & 1,7 & 0,4 & 0,8 & 1,1 & 3,1 & 0,3 & 2,7 \\
\hline 1998 & 1,3 & 3,7 & 0,0 & 1,1 & 0,9 & 1,9 & 0,0 & 0,5 & 0,3 & 0,6 & 5,9 & 17,9 & 1,0 & 1,7 & 0,4 & 0,7 & 0,8 & 2,7 & 0,2 & 2,9 \\
\hline 1999 & 1,0 & 4,0 & 0,0 & 1,0 & 1,0 & 2,2 & 0,0 & 0,5 & 0,3 & 0,7 & 5,6 & 18,2 & 1,2 & 1,9 & 0,5 & 0,8 & 1,0 & 2,6 & 0,2 & 2,1 \\
\hline 2000 & 1,0 & 4,4 & 0,0 & 0,9 & 1,1 & 2,4 & 0,0 & 0,5 & 0,5 & 0,7 & 5,8 & 19,1 & 1,2 & 1,8 & 0,5 & 0,8 & 1,1 & 2,6 & 0,2 & 1,4 \\
\hline 2001 & 0,9 & 5,0 & 0,0 & 1,0 & 1,1 & 2,2 & 0,0 & 0,5 & 0,4 & 0,8 & 6,0 & 19,2 & 1,1 & 1,7 & 0,5 & 0,9 & 1,1 & 2,5 & 0,2 & 1,1 \\
\hline 2002 & 0,9 & 5,3 & 0,0 & 0,8 & 1,1 & 2,2 & 0,0 & 0,6 & 0,4 & 0,8 & 5,8 & 19,5 & 1,1 & 1,6 & 0,5 & 0,9 & 1,0 & 2,4 & 0,2 & 0,9 \\
\hline 2003 & 0,9 & 6,3 & 0,2 & 0,8 & 1,1 & 2,1 & 0,0 & 0,6 & 0,3 & 0,6 & 6,5 & 20,3 & 1,1 & 1,6 & 0,5 & 0,9 & 1,2 & 2,5 & 0,2 & 0,8 \\
\hline 2004 & 1,1 & 6,9 & 0,5 & 1,0 & 1,0 & 2,0 & 0,0 & 0,5 & 0,3 & 0,8 & 6,1 & 18,5 & 1,1 & 1,6 & 0,5 & 0,8 & 1,3 & 3,1 & 0,2 & 0,6 \\
\hline 2005 & 1,4 & 7,9 & 0,7 & 1,3 & 1,0 & 2,2 & 0,1 & 0,5 & 0,2 & 0,5 & 5,2 & 18,0 & 1,1 & 1,6 & 0,5 & 1,0 & 1,0 & 2,3 & 0,2 & 0,7 \\
\hline 2006 & 1,3 & 8,7 & 0,7 & 1,3 & 1,0 & 2,2 & 0,1 & 0,5 & 0,3 & 0,6 & 5,1 & 17,4 & 1,2 & 1,6 & 0,4 & 0,9 & 1,0 & 2,7 & 0,2 & 0,7 \\
\hline 2007 & 1,4 & 9,1 & 0,6 & 1,3 & 1,0 & 2,5 & 0,2 & 0,4 & 0,3 & 0,6 & 5,4 & 16,8 & 0,5 & 1,7 & 0,5 & 1,0 & n.a. & 2,8 & n.a. & 0,7 \\
\hline 2008 & 1,6 & 9,5 & 0,6 & 1,2 & 1,1 & 2,9 & 0,1 & 0,4 & 0,3 & 0,6 & 4,8 & 15,3 & 1,2 & 1,8 & 0,4 & 0,8 & 1,0 & 2,8 & 0,2 & 0,7 \\
\hline 2009 & 1,5 & 8,9 & 0,5 & 1,1 & 1,1 & 2,8 & 0,1 & 0,4 & 0,3 & 0,6 & 5,0 & 16,0 & 1,3 & 1,9 & 0,4 & 0,8 & 0,8 & 2,2 & 0,1 & 0,6 \\
\hline 2010 & 1,2 & 8,3 & 0,4 & 0,9 & 1,0 & 2,5 & 0,1 & 0,4 & 0,2 & 0,7 & 4,7 & 14,7 & 1,2 & 1,7 & 0,3 & 0,7 & 0,6 & 1,6 & 0,1 & 0,4 \\
\hline 2011 & 1,1 & 8,3 & 0,4 & 1,0 & 0,9 & 2,6 & n.a. & n.a. & 0,2 & 0,7 & 4,3 & 14,8 & 1,2 & 1,6 & 0,3 & 0,8 & 0,1 & 1,2 & 0,1 & 0,4 \\
\hline
\end{tabular}

NF National flag, CF Controlled fleet, n.a. Not available

Source: Own elaboration based on data from UNCTAD [38]

The share of the world market accounted for by the European fleet decreased between 1995 and 2012 from $25 \%$ to $21 \%$, but that of the controlled fleet increased (due to growth in foreign flagged vessels). In 1996 the fleet controlled by the EU-15 accounted for $31 \%$ of the global total and that controlled by the EU-27 for 33\%; in
2011 the equivalent figures were $33 \%$ and $34 \%$. However, Table 3 and Fig. 2a-b show that the market shares of both sets of countries peaked in 2008 and began to decrease thereafter.

The share of foreign flagged vessels in the European controlled fleet increased during the reference period

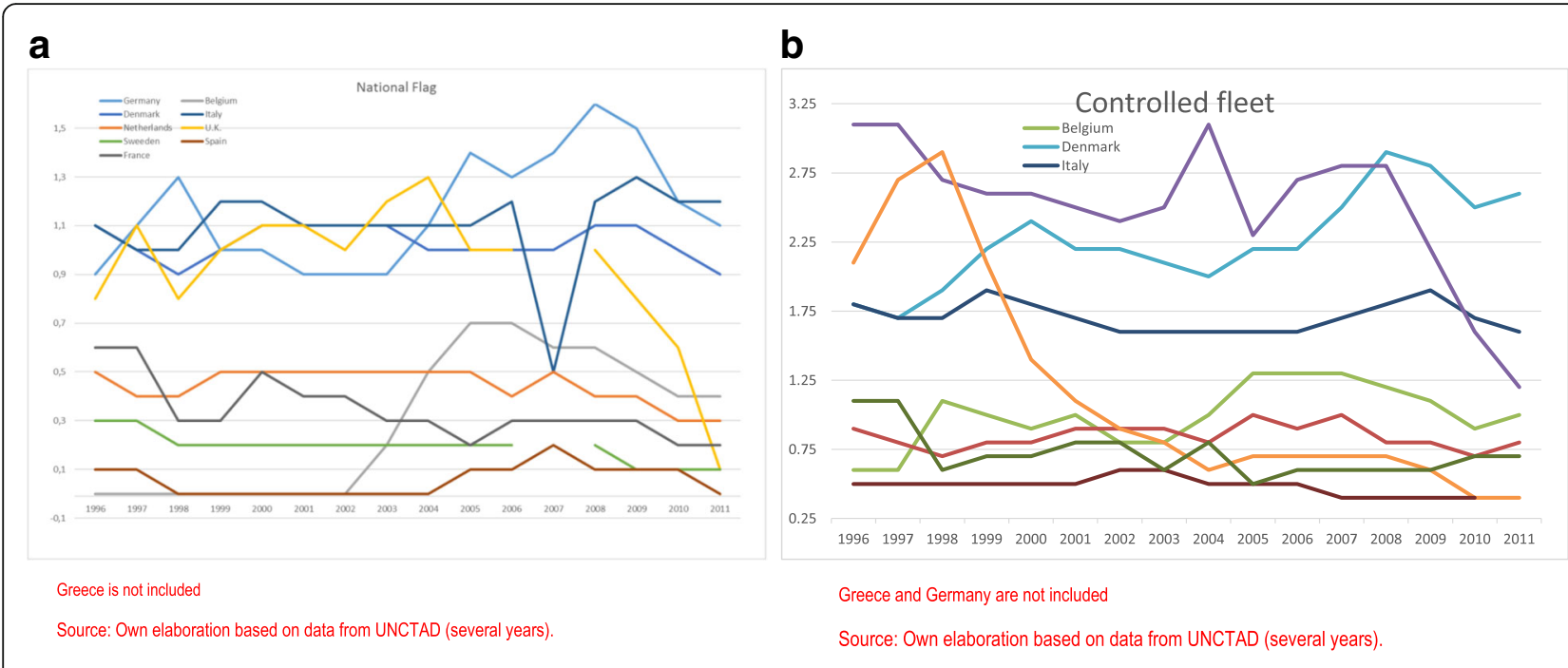

Fig. 2 a Trend in the share of the main EU maritime countries in the world fleet (national flag), 1996-2011 (in \%). Greece is not included. Source: Own elaboration based on data from UNCTAD (several years). $\mathbf{b}$ Trend in the share of the main EU maritime countries in the world fleet (controlled fleet in DWT), 1996-2011 (in \%). Greece and Germany are not included. Source: Own elaboration based on data from UNCTAD (several years) 
Table 4 Tax burden in selected EU countries, 1996-2011 (in \% of GDP)

\begin{tabular}{|c|c|c|c|c|c|c|c|c|c|c|c|c|c|c|c|c|}
\hline \multirow[t]{2}{*}{ Country } & \multicolumn{16}{|c|}{ Tax burden (in $\%$ of GDP) } \\
\hline & 1996 & 1997 & 1998 & 1999 & 2000 & 2001 & 2002 & 2003 & 2004 & 2005 & 2006 & 2007 & 2008 & 2009 & 2010 & 2011 \\
\hline Germany & 35,6 & 35,2 & 35,5 & 36,2 & 36,2 & 35,0 & 34,4 & 34,6 & 33,9 & 33,9 & 34,5 & 34,7 & 35,4 & 36,1 & 35,0 & 35,7 \\
\hline Belgium & 43,0 & 43,5 & 44,1 & 43,9 & 43,6 & 43,5 & 43,6 & 43,1 & 43,2 & 43,1 & 42,8 & 42,6 & 43,0 & 42,1 & 42,4 & 43,0 \\
\hline Denmark & 46,7 & 46,7 & 47,3 & 47,9 & 46,9 & 45,9 & 45,4 & 45,6 & 46,4 & 48,0 & 46,4 & 46,4 & 44,9 & 45,2 & 45,3 & 45,4 \\
\hline Spain & 31,0 & 32,0 & 32,4 & 33,3 & 33,4 & 33,0 & 33,4 & 33,3 & 34,3 & 35,3 & 36,1 & 36,5 & 32,3 & 29,8 & 29,9 & 31,3 \\
\hline France & 43,0 & 43,3 & 43,1 & 43,9 & 43,1 & 42,7 & 42,1 & 42,0 & 42,2 & 42,8 & 43,1 & 42,4 & 42,2 & 41,3 & 41,6 & 42,9 \\
\hline Greece & 34,1 & 28,8 & 30,6 & 31,1 & 33,2 & 32,0 & 32,5 & 31,0 & 30,0 & 31,2 & 30,3 & 31,2 & 31,0 & 30,8 & 32,0 & 33,5 \\
\hline Italy & 40,2 & 41,7 & 40,0 & 40,9 & 40,6 & 40,3 & 39,7 & 40,1 & 39,3 & 39,1 & 40,6 & 41,7 & 41,6 & 42,1 & 41,8 & 41,9 \\
\hline Netherl. & 38,3 & 38,3 & 36,3 & 37,2 & 36,8 & 35,7 & 35,2 & 34,6 & 34,8 & 36,1 & 36,4 & 36,1 & 36,5 & 35,4 & 36,2 & 35,9 \\
\hline R. Unido & 31,7 & 32,3 & 33,8 & 34,5 & 34,7 & 34,7 & 33,3 & 32,9 & 33,4 & 33,8 & 34,4 & 34,1 & 34,0 & 32,3 & 32,8 & 33,6 \\
\hline Sweeden & 47,4 & 48,3 & 48,4 & 48,8 & 49,0 & 46,8 & 45,2 & 45,5 & 45,6 & 46,6 & 46,0 & 45,0 & 44,0 & 44,1 & 43,2 & 42,5 \\
\hline
\end{tabular}

Source: Own elaboration based on data from [30], p. 84-85)

from $60 \%$ to $69 \%$, while the share of vessels sailing under national flags fell from $40 \%$ to $31 \%$.

\section{Formulation \& estimation of models}

We propose two models to compare the relative effectiveness of the maritime policy measures implemented: one for the full set of countries and measures and the other specifically for each maritime nation (the idea being to estimate whether the significance of the measures adopted is similar across all countries).

In formulating the general model the following variables were considered:

- The dependent variable should be the one selected to measure the trend in relative competitiveness of the fleet controlled by each country (Table 3).
- The following explanatory variables were identified: on the one hand the main maritime policy measures adopted (the effectiveness of which we seek to assess) and on the other hand the critical variables which, according to economic literature, conditions the competitiveness of the European fleet (i.e. tax burden and labour costs) (Tables 4 and 5, Figs. 3 and 4).

- The general model thus looks like this:

$Y_{i t}=\alpha_{i}+\beta_{1} X_{1 i t}+\beta_{2} X_{2 i t}+\beta_{3} D_{1 i t}+\beta_{4} D_{2 i t}+u_{i t} \quad \mathrm{i}=1, \ldots$, $10 ; \mathrm{t}=1, \ldots, 16$

where.

- Yit is the percentage share in the cargo capacity (in DWT) of the fleet controlled by the 10 European Maritime nations " $\mathrm{i}$ " out of the global total for the 16 years " $\mathrm{t}$ ";

- $\alpha$ i shows the individual effect for each country;

Table 5 Unitary Labour Cost in selected EU countries, 1996-2011 $(2010=100)$

\begin{tabular}{|c|c|c|c|c|c|c|c|c|c|c|c|c|c|c|c|c|}
\hline \multirow[t]{2}{*}{ Country } & \multicolumn{16}{|c|}{ Unitary labour Cost } \\
\hline & 1996 & 1997 & 1998 & 1999 & 2000 & 2001 & 2002 & 2003 & 2004 & 2005 & 2006 & 2007 & 2008 & 2009 & 2010 & 2011 \\
\hline Germany & 94,3 & 93,4 & 93,7 & 94,6 & 95,2 & 95,0 & 95,6 & 96,6 & 96,2 & 95,8 & 93,5 & 92,7 & 95,0 & 101,5 & 100,0 & 100,5 \\
\hline Belgium & n.a. & n.a. & n.a. & 83,1 & 83,4 & 86,8 & 88,6 & 89,3 & 88,2 & 89,1 & 91,4 & 93,1 & 97,4 & 100,8 & 100,0 & 102,9 \\
\hline Denmark & 71,4 & 71,9 & 74,3 & 75,5 & 76,0 & 79,0 & 82,0 & 83,7 & 83,6 & 85,2 & 86,8 & 91,1 & 96,0 & 100.9 & 100,0 & 104,0 \\
\hline Spain & 69,6 & 71 & 72,3 & 73,7 & 75,5 & 77,8 & 80,1 & 82,5 & 84,9 & 87,8 & 90,7 & 94,5 & 100,1 & 101,6 & 100,0 & 99,1 \\
\hline France & 80,7 & 80,7 & 80,4 & 80,8 & 82,0 & 83,7 & 85,9 & 87,8 & 88,4 & 90,2 & 91,9 & 93,2 & 95,8 & 99,1 & 100,0 & 100,9 \\
\hline Greece & 57,4 & 62,2 & 66,2 & 68,2 & 69,4 & 70,5 & 76,9 & 79,3 & 80,8 & 85,7 & 85,2 & 86,8 & 91,4 & 97,6 & 100,0 & 99,7 \\
\hline Italy & 73,2 & 75,1 & 73,8 & 75,0 & 74,7 & 77,1 & 80,2 & 84,1 & 85,9 & 88,2 & 89,9 & 91,9 & 95,1 & 100 & 100,0 & 100,5 \\
\hline Netherlands & 76,1 & 76,8 & 77,9 & 79,5 & 82,1 & 84,1 & 87,9 & 89,8 & 89,8 & 89,8 & 90,4 & 92,8 & 96,0 & 101,4 & 100,0 & 101,0 \\
\hline R. Unido & 67,0 & 69,1 & 71,5 & 73,7 & 75,9 & 78,8 & 79,4 & 81,1 & 83,8 & 85,1 & 88,6 & 91,6 & 93,3 & 98,0 & 100,0 & 99,5 \\
\hline Sweeden & 80,7 & 82,1 & 78,8 & 79,9 & 83,4 & 87,3 & 88,3 & 89,2 & 88,4 & 89,1 & 89,0 & 92,8 & 97,3 & 102,9 & 100,0 & 102,6 \\
\hline
\end{tabular}




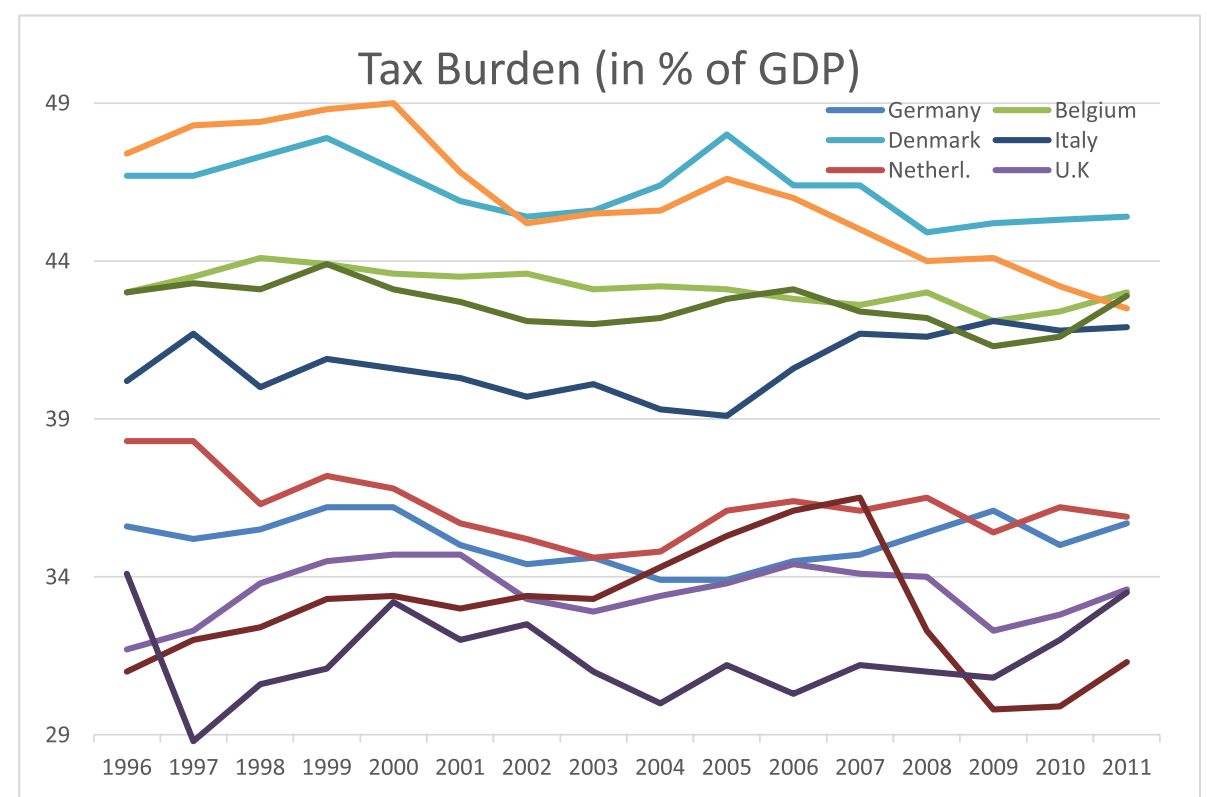

Source: Own elaboration based on data from OECD Statistics (2015, p. 84-85).

Fig. 3 Tax burden in selected EU countries, 1996-2011 (in \% of GDP). Source: Own elaboration based on data from [29], p. 84-85)

- X1it is the "tax burden" variable (in \% of GDP) in country "i" for year " $\mathrm{t}$ ";

- X2it is the "unit labour cost" variable (base year 2010) in country " $\mathrm{i}$ " for year " $\mathrm{t}$ ";

- D1it is a dummy variable that takes a value of 1 as from the year following " $\mathrm{t}$ " in which country " $\mathrm{i}$ " adopts tonnage tax (the instrument generally used) as a promotional measure;

- D2it is a dummy variable that takes a value of 1 as from the year following " $\mathrm{t}$ " in which country " $\mathrm{i}$ " adopts other promotional policies (setting up a 2nd registry and other ways of reducing operating costs or providing aid);

- $\mathrm{u}_{\mathrm{it}}$ is the error term.

- The following model was also drawn up for each of the 10 countries:

$$
Y_{t}=\beta_{0}+\beta_{1} X_{1 t}+\beta_{2} X_{2 t}+\beta_{3} D_{1 t}+\beta_{4} D_{2 t}+u_{t}
$$

where.

-Yt, is the percentage share in the cargo capacity (in DWT) of the fleet controlled by the country out of the global total for year " $t$ ";

- $\beta 0$ is the independent term;

- X1t is the "tax burden" variable (in \% of GDP) for the country for year " $t$ ";
- X2t is the "unit labour cost" variable (base year 2010) for the country for year " $t$ ";

- D1t is a dummy variable that takes a value of 1 as from the year following " $t$ " in which the country in question" adopts tonnage tax as a promotional measure;

- D2t is a dummy variable that takes a value of 1 as from the year following " $t$ " in which the country in question" adopts other promotional policies;

$-u_{t}$ is the error term.

\subsection{Estimates and results}

- The estimation results for the general model in which the dependent variable is the share of the fleet controlled by each country in the global total are shown in Table 6. A fixed effects model is estimated, because apart from the fact that we are seeking to estimate the country effect we also use the Hausman test to gauge which estimator is best suited to the model proposed. ${ }^{7}$ Moreover, the high R-squared LSDV (0.972598) confirms that the model is properly specified.

Most of the variables considered are statistically significant and have the signs expected. The introduction of these measures (tonnage tax/second register and

\footnotetext{
${ }^{7}$ The result of the test leads us to estimate a fixed effect model.
} 


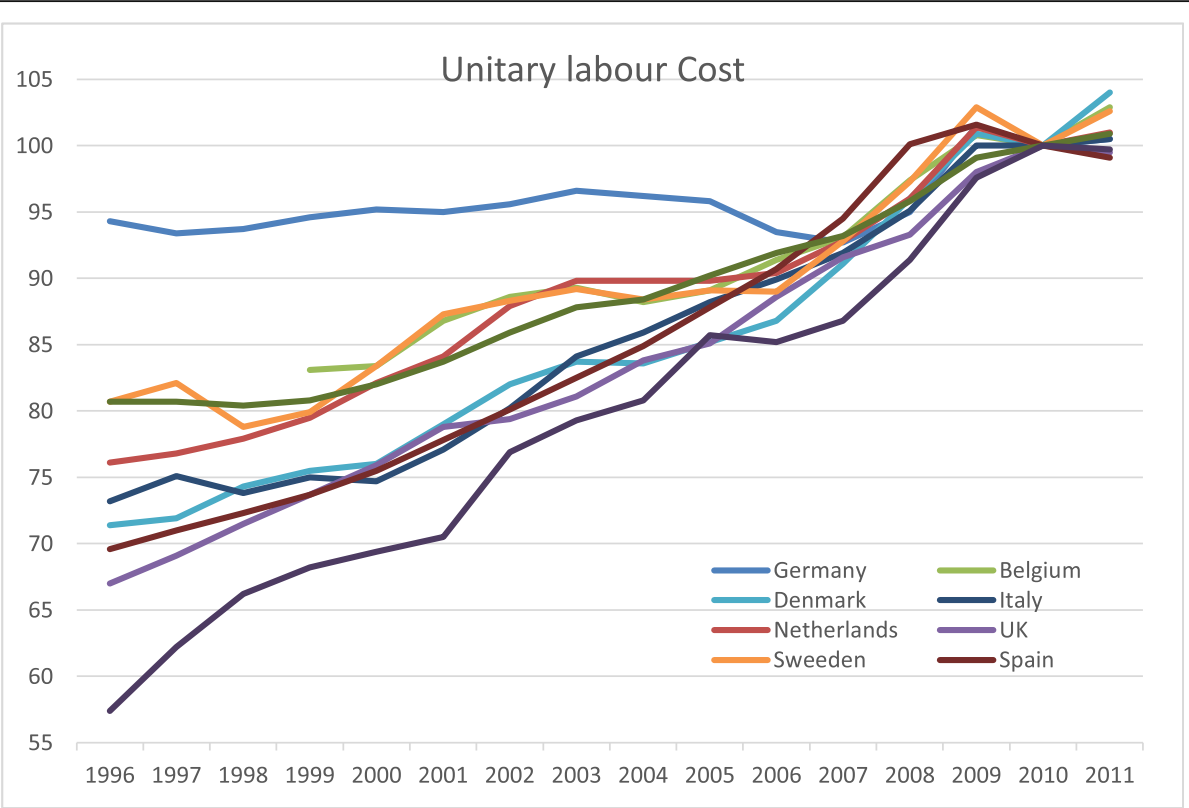

Source: Own elaboration based on data from OECD Statistics (2016).

Fig. 4 Unitary Labour Cost in selected EU countries, 1996-2011 (2010=100). Source: Own elaboration based on data from OECD [29]

other measures) has apparently been effective and has had a positive effect on the trend in the controlled fleet (they have direct, significant links with it). Tonnage tax seems to have had the greatest impact the judge from the fact that it has the highest coefficient. As for the context variables which are theoretically relevant, only unit labour costs seem to have had any negative conditioning effect on the trend in the controlled fleet (the coefficient of -8.06 is striking); the tax burden does not seem to be significant in explaining the dependent variable.

Table 6 Regression estimates of impact of maritime transport policy measures on controlled fleet (general model)

\begin{tabular}{ll}
\hline Variables & Coefficients \\
\hline Constant & $11,1036^{* * *}$ \\
& $(2,83)$ \\
Tonnage Tax & $114539^{* * *}$ \\
Second register and other measures & $(0,23)$ \\
& $0,683,649^{* * *}$ \\
Labour Unitary Cost & $(0,22)$ \\
Tax burden & $-806295^{* * *}$ \\
& $(1,32)$ \\
$R^{2}$ MCVF (LSDV) & $-366,734$ \\
\hline
\end{tabular}

Notes: Standard deviations in parentheses; ${ }^{*} p<0.05,{ }^{* *} p<0.01,{ }^{* * *} p<0.001$
- The results of the OLS estimation for each of the 10 countries are outlined in Table 7. Tonnage tax is shown to be significant only in the trends in the fleets of Germany and Belgium. The other measures introduced (including second registers) are significant for Germany, Greece, the Netherlands and Sweden, though only in the case of Germany do they show the positive sign expected (direct link with competitiveness). The context variables are significant only in certain countries: unit labour costs in Denmark, the Netherlands and the UK and the tax burden only in Italy.

\section{Conclusions}

1. In spite of the Community guidelines on state aid to maritime transport, the degree to which the schemes set up are used seems to mean that some European registries are more competitive than others (there are also differences in the requirements concerning the proportion of foreign nationals in crews and in manning levels, which are determinant factors in the operating costs of vessels). This distorts competition within the EU. Thus, according to data from the UNCTAD [40], in 2011:

- In Germany there were 438 ships registered under other European registries compared to 422 sailing under the German flag. In terms of capacity the tonnage flagged in Germany (17.3 million DWT) 
Table 7 Regression estimates of impact of maritime transport policy measures on controlled fleet (country-specific model)

\begin{tabular}{|c|c|c|c|c|c|c|c|c|c|c|}
\hline VariablelCountry & Germany & Belgium & Danmark & Spain & France & Greece & Italy & Netherl. & U.K & Sweeden \\
\hline Constant & $\begin{array}{l}10,659(11 \\
18)\end{array}$ & $\begin{array}{l}3796(6, \\
48)\end{array}$ & $\begin{array}{l}-0,816(4, \\
16)\end{array}$ & $\begin{array}{l}0,213(0, \\
45)\end{array}$ & $\begin{array}{l}-0,590 \\
(5,10)\end{array}$ & $\begin{array}{l}15,63^{*}(7 \\
31)\end{array}$ & $\begin{array}{l}-1254 \\
(1,79)\end{array}$ & $\begin{array}{l}0,409(1 \\
24)\end{array}$ & $6014(4,14)$ & $\begin{array}{l}10,357(11, \\
21)\end{array}$ \\
\hline Tonnage Tax & $\begin{array}{l}1998 * * *(0, \\
63)\end{array}$ & $\begin{array}{l}0,369 *(0, \\
12)\end{array}$ & $\begin{array}{l}-0,175(0 \\
19)\end{array}$ & $\begin{array}{l}-0,082 \\
(0,06)\end{array}$ & $\begin{array}{l}-0,236 \\
(0,19)\end{array}$ & $\begin{array}{l}-0,687(1 \\
19)\end{array}$ & $\begin{array}{l}-0,007 \\
(0,13)\end{array}$ & $\begin{array}{l}-0,132(0, \\
09)\end{array}$ & $\begin{array}{l}0,294(0, \\
36)\end{array}$ & n.a. \\
\hline $\begin{array}{l}\text { Second register and other } \\
\text { measures }\end{array}$ & $\begin{array}{l}3129 * * * * \\
46)\end{array}$ & n.a. & $\begin{array}{l}0,191(0, \\
23)\end{array}$ & $\begin{array}{l}0,021(0, \\
05)\end{array}$ & $\begin{array}{l}0,139(0, \\
17)\end{array}$ & $\begin{array}{l}-3440^{* * *} \\
(1,06)\end{array}$ & $\begin{array}{l}0,049(0, \\
07)\end{array}$ & $\begin{array}{l}-0,209 * * \\
(0,08)\end{array}$ & n.a. & $\begin{array}{l}-1023^{* *} \\
(0,39)\end{array}$ \\
\hline Labour Unitary Cost & $1099(9,53)$ & $\begin{array}{l}-1716(0, \\
99)\end{array}$ & $\begin{array}{l}2684^{*}(1 \\
58)\end{array}$ & $\begin{array}{l}-0,069 \\
(0,33)\end{array}$ & $\begin{array}{l}-0,248 \\
(1,84)\end{array}$ & $3046(5,92)$ & $\begin{array}{l}-0,641 \\
(0,58)\end{array}$ & $\begin{array}{l}0,808 *(0 \\
45)\end{array}$ & $\begin{array}{l}-4212^{* *} \\
(1,59)\end{array}$ & $\begin{array}{l}-5416(3 \\
86)\end{array}$ \\
\hline Tax burden & $\begin{array}{l}-23,347 \\
(32,48)\end{array}$ & $\begin{array}{l}-3252 \\
(13,68)\end{array}$ & $\begin{array}{l}\text { 1799 (7, } \\
51)\end{array}$ & $\begin{array}{l}1066(0, \\
87)\end{array}$ & $\begin{array}{l}3730(9, \\
36)\end{array}$ & $\begin{array}{l}2326(21 \\
53)\end{array}$ & $\begin{array}{l}8521^{*}(4, \\
07)\end{array}$ & $\begin{array}{l}-0,326(2 \\
67)\end{array}$ & $\begin{array}{l}-0,555(11, \\
85)\end{array}$ & $\begin{array}{l}-8029(17, \\
53)\end{array}$ \\
\hline$R^{2}$ & 0,9219 & 0,6085 & 0,7482 & 0,5885 & 0,3549 & 0,7104 & 0,4043 & 0,4467 & 0,4775 & 0,7942 \\
\hline N & 16 & 13 & 16 & 15 & 16 & 16 & 16 & 16 & 16 & 16 \\
\hline
\end{tabular}

n.a. Not available

Notes: Standard deviations in parentheses; ${ }^{*} p<0.05$, ${ }^{* *} p<0.01,{ }^{* * *} p<0.001$

exceeded the tonnage sailing under other European flags (10.2 million DWT).

- In France the capacity of the fleet controlled by French shipowners but sailing under other European registries totalled 4.24 million DWT, which means it exceeded that of the fleet sailing under the French flag (3.43 million DWT).

- Increase there were 692 vessels flagged under other European registries, with a total capacity of 44.55 million DWT, compared to 738 vessels with a capacity of 64.92 million DWT sailing under the Greek flag.

- In the UK vessels sailing under other European flags accounted for a capacity of 1.68 million DWT compared to 2.09 million DWT for vessels flagged in the UK.

- In Sweden vessels sailing under other European flags accounted for 1.66 million DWT, and thus exceeded the 1.07 million DWT in capacity registered under the Swedish flag.

2. In general the measures adopted in national-level maritime policies (tonnage tax, second register and other measures) seem to have been effective in that they have had a positive effect on the competitiveness of controlled fleets. Relatively speaking, tonnage tax seems to have had the greatest impact. As for the context variables which are theoretically relevant, unit labour costs seem to have had a negative conditioning effect on the trend in the controlled fleet, but the tax burden does not. This result confirms some earlier studies conducted in the UK [23] and in the EU (positive correlations were found between the different regimes of state aid and increases in the size of fleets and the number of jobs for seafarers between 1997 and 2004, according to Lloyd and AMRIE [25]).
3. The impact of these measures on the controlled fleets by UE countries has not been consistent: in some cases, such as Germany, they have had a clear, direct, strong effect while in others, such as the Netherlands and Greece, they have completely failed to reverse the trend towards lower competitiveness of national fleets.

4. State aid seems to be effective in the early years of its application, even in terms of national flags. Once the competitive edge disappears an increase in the proportion of foreign flagged vessels in fleets is observed. Marlow and Mitroussi [27] also found that the perceived benefit of tonnage tax is greater in the first few years after its introduction. The overall increase in foreign flagged vessels in the European controlled fleet (from 58\% in 1996 to 69\% in 2011) is a sign that $\mathrm{EU}$ national flags were not competitive on the international market in spite of the introduction of aid. However, country effects are also highly significant here: there are countries in which the share of foreign flagged vessels increased in the years following the introduction of incentives (from $66 \%$ to $86 \%$ in Germany, from $43 \%$ to $66 \%$ in Denmark, from $47 \%$ to $69 \%$ in France and from $38 \%$ to $63 \%$ in the Netherlands) and others in which it decreased (from $97 \%$ to $54 \%$ in Belgium due to the transfer of the Luxembourg flagged fleet to its own national registry, from $81 \%$ to $70 \%$ in Spain, from $43 \%$ to $28 \%$ in Italy, from $62 \%$ to $60 \%$ in the UK and from $85 \%$ to $79 \%$ in Sweden).

\section{Acknowledgements}

The authors acknowledge research funding from University of the Basque Country (grant GIU19/078); Econometrics Research Group (Basque

Government Department of Education grant IT-1359-19) and Spanish Ministry of Economy, Industry and Competitiveness and ERDF (grant PID2019105986GB-C22). 


\section{Authors' informations}

Biography:

Javier Bilbao-Ubillos is graduated in Economics and Law, and obtained his Doctorate in 1990. Now he is a Professor in the Department of Applied Economics I of the University of the Basque Country (Spain). He is the author (or co-author) of 21 books and 61 articles in journals as European Urban and Regional Studies, Administration \& Society, Economic \& Political Weekly, Transportation Research Part A: Policy and Practice, International Journal of Social Welfare, Journal of Economic Policy Reform, Sustainable Development, Public Money \& Management, Social Indicators Research, Economic Development Quarterly, The European Review or Transportation Letters.

Biography:

Ana Fernández-Saiz is graduated in Economics, and obtained her Doctorate in 1991. Now she is a Professor in the Department of Applied Economics III of the University of the Basque Country (Spain). She is the author (or coauthor) of 15 books and 55 articles in journals.

Research interests: Transport Policy, Econometrics, Labour market, Globalization

Biography:

Rosa Payan-Azkue is graduated in Economics, and obtained her Doctorate in 2015.

\section{Authors' contributions}

All authors of this research paper have directly participated in the planning, execution, or analysis of this study. Rosa Payán-Azkue found data and material and wrote the first draft; Ana Fernández-Sainz was in charge of econometric regressions; and Javier Bilbao-Ubillos selected the best approach to the subject and was responsible for the interpretation in terms of policy analysis. All authors read and approved the final manuscript.

\section{Availability of data and materials}

Data will be available on request.

\section{Competing interests}

The authors declare that they have no competing interests.

\section{Author details}

'Department of Applied Economics I, University of the Basque Country (UPV/ EHU), Avda. Lehendakari Agirre, 83, 48105 Bilbao, Spain. ${ }^{2}$ Department of Applied Economics III, University of the Basque Country (UPV/EHU), Bilbao, Spain.

Received: 9 July 2020 Accepted: 21 December 2020

Published online: 11 January 2021

\section{References}

1. Adriaansens, M. (2009). Choosing a profitable course. European tonnage tax regimes for the shipping industry. Brussels: Price Waterhouse Coopers Available at: https://www.pwc.be/en_BE/be/transport-logistics/pdf/ Choosing-a-profitable-course-Tonnage-tax.pdf

2. ANAVE (Spanish Shipowners' Association) (2014). Merchant marine and maritime transport. Madrid: ANAVE Available at: http://www.anave.es/ marina-mercante/81-marina-mercante.

3. Audige, M. (1995). Maritime transport serving west and Central African countries: Trends and issues. In Sub-Saharan Africa transport policy Programm, working paper $n^{\circ}$ 16. Washington, D.C.: World Bank and ECA.

4. Beall, J. (edr.) (2017). The European maritime transport policy with respect to sustainable development issues and climate commitments. Official Gazette of the French Republic, 11 may 2017.

5. Bergantino, A., \& Marlow, P. (1998). Factors influencing the choice of flag: Empirical evidence. Maritime Policy \& Management., 25(2), 157-174.

6. Bredima, A., \& Tzoannos, J. (1990). The common shipping policy of the EC. Amsterdam: Elsevier Science Publishers B.V.

7. Chen, J., Lib, K. X., Liuc, X., \& Li, H. (2017). The development of ship registration policy in China: Response to flags of convenience. Marine Policy, $83,22-28$

8. Council of the European Union (2017a). Council conclusions on "priorities for the EU's maritime transport policy until 2020: Competitiveness, Decarbonisation, digitalisation to ensure global connectivity, an efficient internal market and a world-class maritime cluster" 9976/17. Brussels, 8 June 2017.
9. Council of the European Union (2017b). Declaration of the European ministers responsible for the integrated maritime Policyon blue growth-Valletta declaration 8037/17. Brussels, 10 April 2017.

10. Danske, R. (2018). Danish shipping facts and figures. Copenhagen: Danske Rederier/Danish Shipping.

11. European Commission (2014). Report from the commission to the council "Fifth report on the implementation of Council Regulation (EEC) No $3577 / 92$ applying the principle of freedom to provide services to maritime cabotage (2001-2010)". COM (2014) 231 final Brussels, 22.4.2014.

12. European Commission (2004a). Community guidelines on state aid for rescuing and restructuring firms in difficulty. Commission communication (2004/C 244/02) 1 October 2004.

13. European Commission (2004b). Community guidelines on State aid to maritime transport. Commission communication C(2004) 4317 January 2004.

14. European Commission (1997). Community guidelines on state aid to maritime transport. Commission communication (97/C205/05) 5 July 1997.

15. European Commission (1996). Towards a new maritime strategy Communication from the Commission to the Council, the European Parliament, the Economic and Social Committee and the Committee of the Regions COM (96) 81 final, 13 March 1996.

16. European Commission (1989). A future for the community shipping industry: Measures to improve the operating conditions of community shipping Commission communication COM (89) 266 final, 3 August 1989.

17. European Commission (1985). Progress towards a common transport policy. Maritime transport Commission communication and proposals to the Council transmitted on 19 March 1985. COM (85) 90 final, 14 March 1985. Bulletin of the European Communities, Supplement 5/85.

18. Eurostat (2013). EU transport in figures. In Statistical pocketbook 2013. Luxembourg: Publications Office of the European Union.

19. Gregory, W. R. (2012). Flags of convenience: The development of open registries in the global maritime business and implications for modern seafarers Thesis submitted to the Faculty of The School of Continuing Studies, Georgetown University. November 1, 2012.

20. International Labour Organization (ILO) (2001). The impact of seafarers' living and working conditions of changes in the structure of the shipping industry. Report JMC/29/2001/3. Geneva: ILO Available at: http://www.ilo.org/public/ libdoc/ilo/2001/101B09 3 engl.pdf.

21. International Transport Worker's Federation (ITF) (2011). Flags of convenience London: ITF Available at: http://www.itfglobal.org/en/transport-sectors/ seafarers/in-focus/flags-of-convenience-campaign/.

22. Kiriazidis, T., \& Tzanidakis, G. (1995). Recent aspects of the EU maritime transport policy. Maritime Policy \& Management, 22(2), 179-186.

23. Leggate, H. (2005). Tonnage tax and employment UK seafarers. Memorandum. London: British Parliament Available at: http://www.publications.parliament. uk/pa/cm200405/cmselect/cmtran/299/299we04.htm.

24. Lekakou, M. B., Stefanidaki, E., Katsounis, I., Remoundos, G., \& George Arvanitakis, G. (2018). Short Sea shipping in Greece: Data, impact and challenges. Mombasa: Paper presented at the 26th Annual Conference of the International Association of Maritime Economists Available from: https://www.researchgate.net/publication/342720467_Short_Sea Shipping_in_Greece_Data_impact_and_challenges [Äccessed 29 Sep 2020].

25. Lloyd, M., \& AMRIE (2006). Maritime state aids towards and assessment and monitoring framework. Brussels: Maritime Transport Coordination Platform Available at: http://www.maritimetransport.net/mtso/downloads/Public Information/MTCP_report_Impact_of_State_Aid_study.pdf.

26. Luo, M., Fan, L., \& Li, K. X. (2013). Flag choice behavior in the world merchant fleet. Transportmetrica A: Transport Science, 9(5), 429-450.

27. Marlow, P., \& Mitroussi, K. (2011). Shipping taxation: Perspectives and impact on flag choice. International Journal Shipping and Transport Logistics, 3(4), 349-364.

28. Metaxas, B. N. (1981). Flags of convenience. Marine Policy, 5(1), 52-66.

29. OECD (2016). Statistics. Unit labour costs and labour productivity (employment based), Total economy Available at: https://stats.oecd.org/Index. aspx?DataSetCode $=$ ULC EEQ

30. OECD (2015). Revenue statistics 2015.Tax levels and tax structures, 19652014 Available at: http://www.oecd.org/ctp/tax-policy/revenue-statistics-1 9963726.htm

31. Paixao, A. C., \& Marlow, P. B. (2001). A review of the European Union shipping policy. Maritime Policy \& Management, 28(2), 187-198. 
32. Paixao, A. C., \& Marlow, P. B. (2005). The competitiveness of short sea shipping in multimodal logistics supply chains: Service attributes. Maritime Policy \& Management, 32(4), 363-382.

33. Pallis, A. A. (2017). The common EU maritime transport policy: Policy Europeanisation in the 1990s. London: Routledge.

34. Ready, N. (1998). Ship registration, (2nd ed.). London: Lloyd's of London.

35. Roe, M. (2013). Maritime governance and policy-making. London: SpringerVerlag.

36. Sdoukopoulos, L., Boile, M., \& Gagatsi, E. (2011). European maritime transport policy and research priorities. Santiago de Chile: Paper presented at the International Association of Maritime Economists 2011 Conference the 25th - 28th of October 2011.

37. Thanopoulou, H. A. (1998). What price the flag? The terms of competitiveness in shipping. Marine Policy, 22(4-5), 359-374.

38. UNCTAD (n.d.). Review of maritime transport. Geneva: UNCTAD.

39. UNCTAD. (2008). Review of Maritime Transport. Geneva: UNCTAD.

40. UNCTAD. (2012). Review of Maritime Transport. Geneva: UNCTAD.

41. UNCTAD. (2015). Review of Maritime Transport. Geneva: UNCTAD.

42. Yannopoulos, G. N. (1988). The economics of "flagging out". Journal of Transport Economics and Policy, 22, 197-207.

43. Zamora, J. (2003). La desgracia del prestige. Barcelone: Available at: https: www.ceida.org/prestige/Documentacion/Prestige.doc.

\section{Publisher's Note}

Springer Nature remains neutral with regard to jurisdictional claims in published maps and institutional affiliations.

\section{Submit your manuscript to a SpringerOpen ${ }^{\circ}$ journal and benefit from:}

- Convenient online submission

- Rigorous peer review

- Open access: articles freely available online

- High visibility within the field

- Retaining the copyright to your article

Submit your next manuscript at $\boldsymbol{\nabla}$ springeropen.com 